IFAS Extension

\title{
Armillaria Root Rot (Also known as Mushroom Root Rot, Shoestring Root Rot, Honey Mushroom Rot) ${ }^{1}$
}

\author{
Laura Sanagorski, Aaron Trulock, and Jason Smith²
}

\section{Summary}

Armillaria root rot is a disease that decays the root system of many common trees and shrubs. It is caused by several species of Armillaria, fungi that can be recognized by the clusters of yellow to honey-colored mushrooms that emerge during moist conditions. The disease is often lethal, and infected trees may have wilting branches, branch dieback, and stunted growth. Infected trees and shrubs should be removed and replaced with resistant species (Table 1).

\section{Introduction}

Armillaria spp. cause root and butt rot of trees and shrubs worldwide, from tropical to boreal regions (Sinclair and Lyon 2005). Armillaria spp. have a wide host range, including many hardwoods and conifers. The fungus infects the roots and bases of trees, causing them to decay, weaken, or die. Some species of Armillaria are primary pathogens, capable of attacking and killing trees, but others are opportunistic pathogens that kill only unhealthy or stressed trees. In some western conifer forests, Armillaria is considered a major forest pathogen, and silvicultural practices must be tailored to prevent major tree loss (Hagle 2008). In Florida, Armillaria tabescens is the most common pathogenic species (Sinclair and Lyon 2005) and is primarily an opportunistic pathogen, but it may kill seemingly healthy trees and shrubs in both urban and natural areas, particularly when host species are stressed.

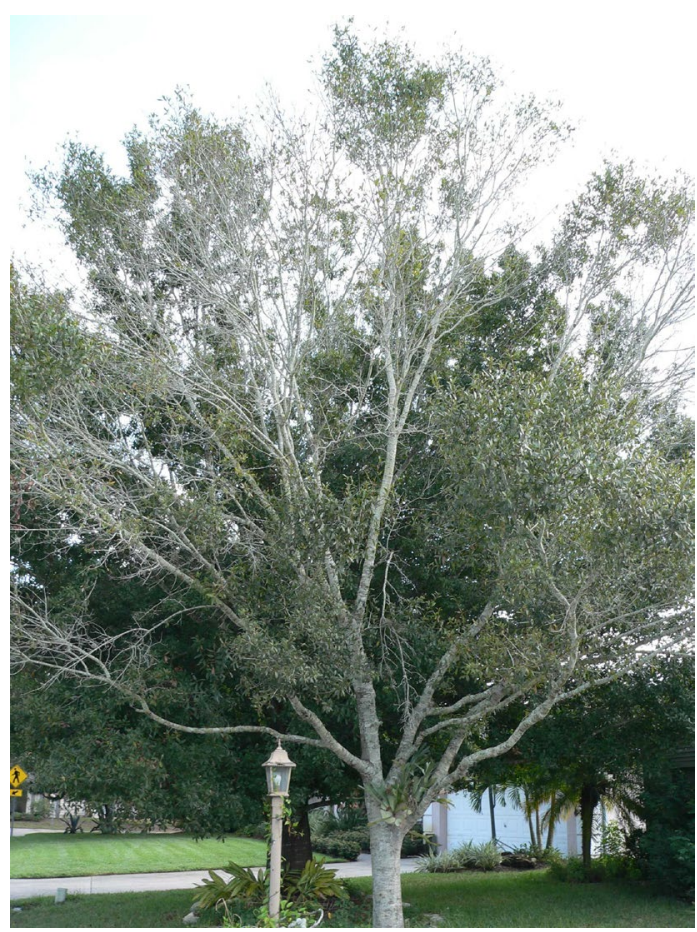

Figure 1. Thinning foliage of a laurel oak (Quercus hemisphaerica) infected with Armillaria tabescens.

Credits: Jason Smith

1. This document is ENH1217, one of a series of the Environmental Horticulture Department, UF/IFAS Extension. Original publication date July 2013. Visit the EDIS website at http://edis.ifas.ufl.edu.

2. Laura Sanagorski, assistant professor, Agricultural Education and Communication; Aaron Trulock, graduate research assistant, School of Forest Resources and Conservation; and Jason Smith, associate professor, School of Forest Resources and Conservation, UF/IFAS Extension, Gainesville, FL 32611. 


\section{Signs and Symptoms}

Trees with Armillaria root rot display one or more of the following symptoms:

- Fading, wilting, or thin foliage (Figure 1)

- Overall decline

- Dead branches

- Branch or trunk failure

- Dieback (Figure 2)

- Stunted growth

- Death (Figure 2)

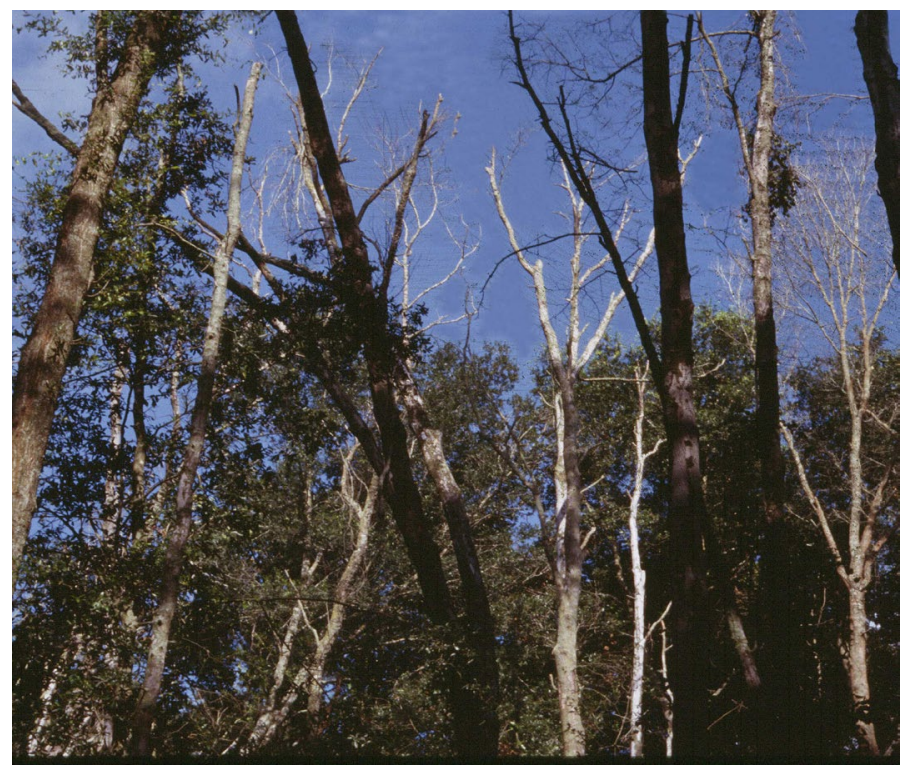

Figure 2. Oak stand exhibiting pocket mortality typical of Armillaria root rot.

Credits: Ed Barnard

During high winds, trees infected with Armillaria may break from the weakened base and cause damage or injury. Large trees infected with Armillaria are considered hazard trees and should be removed when near targets, such as property or people.

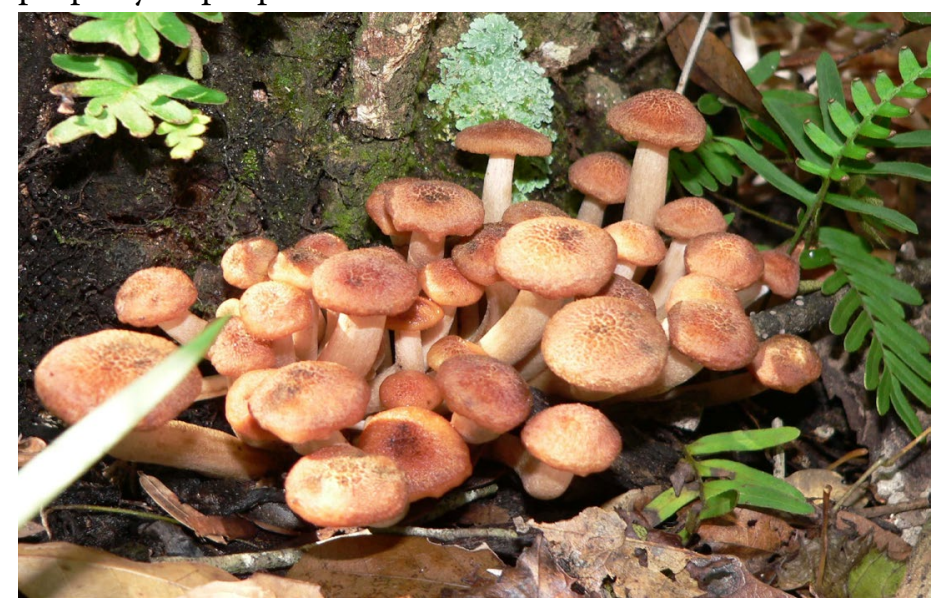

Figure 3. Young developing mushrooms of Armillaria tabescens. Credits: Jason Smith

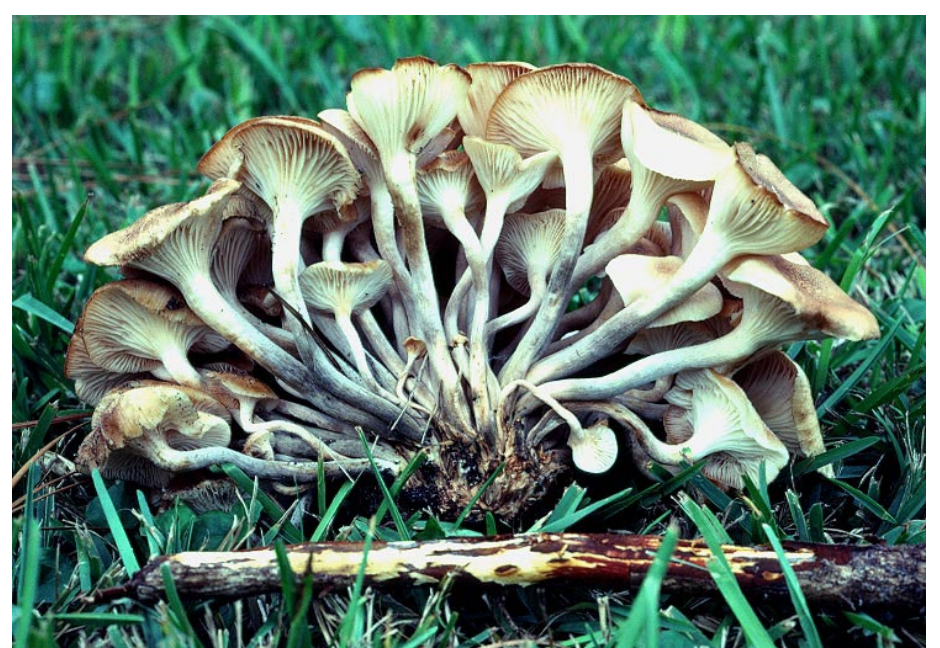

Figure 4. Mature mushrooms of Armillaria tabescens and root of an oak infected with the pathogen.

Credits: Ed Barnard

Armillaria root rot can be easily recognized by a few distinct signs. Clusters of short-lived yellowish to honeybrown mushrooms (Figures 3 and 4) are the reproductive structures of the fungus and are usually observed when there are cool, moist conditions during the fall and winter, or occasionally in late spring. The mushrooms often occur at the base of an infected tree (Figure 5) or on and near stumps of previously killed trees (Figure 6), but they may also grow from the underground roots of an infected tree away from the main stem. White fans of mycelia (the vegetative form of the fungus) (Figure 7) can be observed under the bark of stems and roots of infected trees. The purpose of the mycelia is to absorb nutrients and decompose dead vegetative matter. The mycelia of most Armillaria species is bioluminescent (it glows in the dark); however, that is not the case for Armillaria tabescens, the most common species in Florida. Armillaria can also be identified by dark, string-like, underground mycelial growths known as rhizomorphs (Figure 8), which originate at the infected root system.

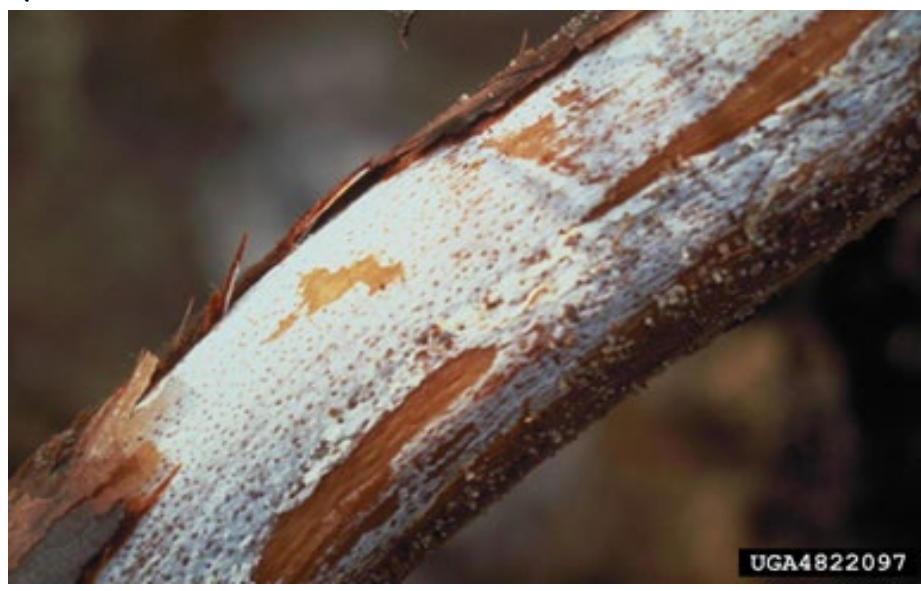

Figure 5. White mycelial fan under the bark of a root infected with Armillaria tabescens.

Credits: Ed Barnard 


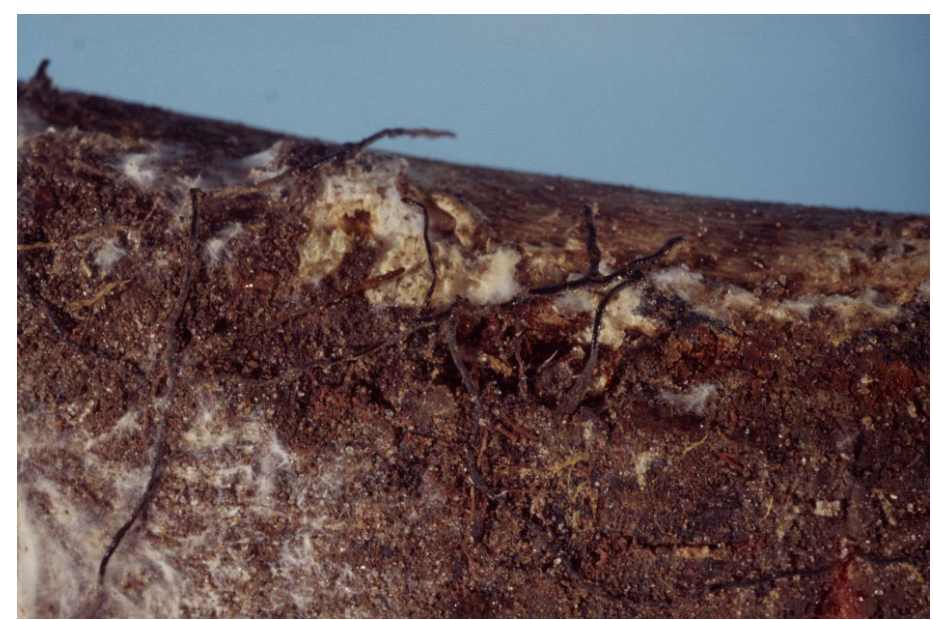

Figure 6. Rhizomorphs of Armillaria spp. produced under the bark of an infected root.

Credits: Ed Barnard

Armillaria rhizomorphs are also vegetative parts of the fungus. They are thick mycelial growths that transport nutrients and increase the fungus's size. Rhizomorphs look like long, black shoestrings, giving Armillaria root rot the nickname "shoestring root rot." They are frequently overlooked because they blend in with the tree's existing root system. This is especially true with trees that tend to have many aerial and surface roots, such as those in the Ficus species. However, rhizomorphs are frequently absent in Florida.

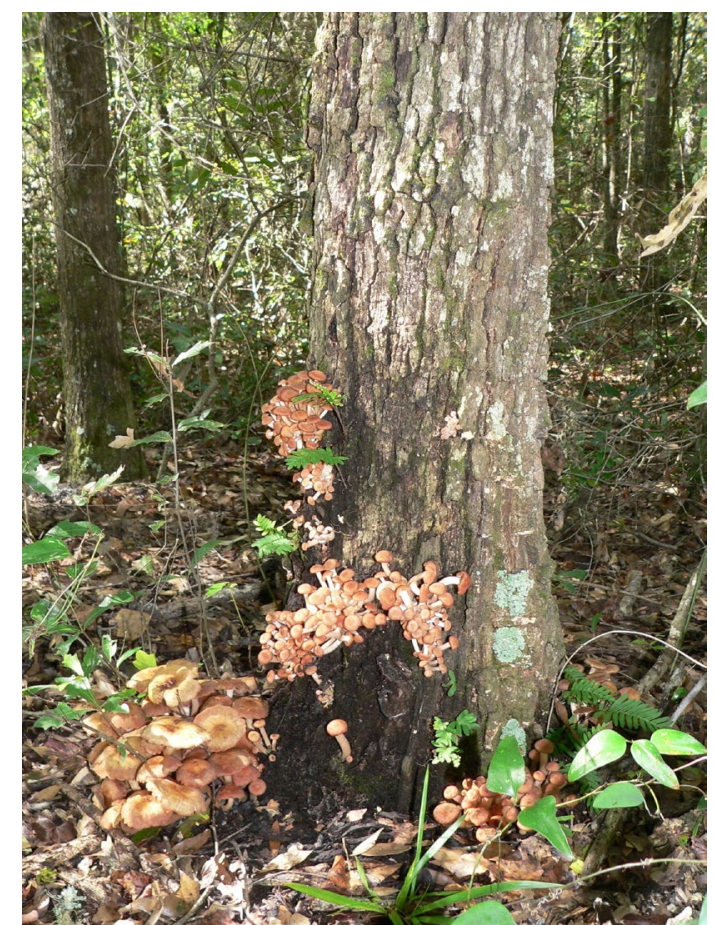

Figure 7. Mushrooms of Armillaria tabescens at the base of an infected mockernut hickory (Carya tomentosa).

Credits: Jason Smith

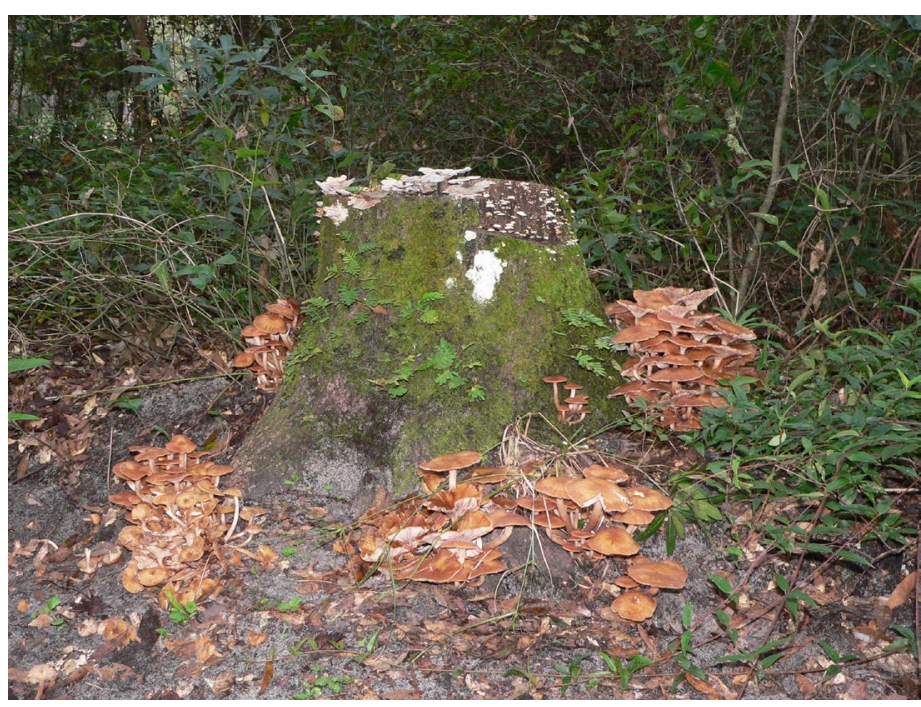

Figure 8. Armillaria tabescens fruiting near a stump of a previously killed laurel oak.

Credits: Jason Smith

Armillaria root rot in Florida is primarily caused by Armillaria tabescens and Armillaria mellea (Alfieri et al. 1984). The disease is found primarily on hardwoods, especially oaks (Quercus spp.) and hickories (Carya spp.). It spreads through the soil by the movement of the rhizomorphs that spread from infected trees to adjacent noninfected roots and stumps (Sinclair and Lyon 2005). Root-to-root contact is important for disease transmission. Damaged roots are susceptible to infection; however, healthy roots apparently resist infection (Sinclair and Lyon 2005). In both natural and urban landscapes, Armillaria root rot is often a secondary condition that affects a stressed tree. Drought, disease, pest infestation, cold injury, planting too deep, overpruning, and improper fertilization are some of the stresses that may initially affect trees.

Armillaria root rot can spread both between trees and shrubs by either airborne spores that come from mushrooms at the base of the trunk, or by the rhizomorphs. One infected tree can infect neighboring trees and shrubs through close root association or open wounds. An infected landscape tree may serve as inoculum for shrubs and other trees. For example, Armillaria may spread from an infected oak to azaleas planted underneath it and to other trees in the yard. Because of the nature of the disease spread, it is not uncommon to find groupings of trees and plants affected by Armillaria. 


\section{Management}

As with many landscape disorders, the most appropriate management technique is the avoidance of infection.

Maintain healthy trees by using proper pruning, fertilization, irrigation, and pest management practices. One should commit to planting a more diverse landscape because they tend to better withstand pests, diseases, and even severe weather events.

Symptoms of Armillaria root rot often do not appear until 1-3 years after infection has taken place. Therefore, it is difficult, if not impossible, to save trees once they become infected. There are no fungicidal cures for Armillaria. However, fungicidal soil treatments can be used at planting to reduce the likelihood of infection in newly planted trees (Cox, Scherm, and Beckman 2004). Always disinfect pruning tools between plants to reduce the possibility of transmitting diseases. Some plants that have only a small area of infected roots or root collar may be saved by exposing the area to aeration, drying the fungus, and halting growth (Sinclair and Lyon 2005). Because Armillaria spp. can live in dead stumps and roots for years, an infected tree or shrub should be completely removed, including the stump and major roots. Replanting a resistant (Table 1) species (Davidson and Byther 1994; Raabe 2008) can follow tree removal (Worrall 2007), but special care should be taken not to damage the new plant's root system. Removal of other susceptible trees or shrubs near the infected plant may be necessary to prevent the disease from spreading over a large area (Williams et al. 1986).

\section{References}

Alfieri, S. A. Jr., K. R. Langdon, J. W. Kimbrough, N. E. El-Gholl, and C. Wehlburg. 1984. Index of Plant Diseases in Florida (Revised). Bulletin 14. Tallahassee: Florida Department of Agriculture and Consumer Services Division of Plant Industry.

Cox, K. D., H. Scherm, and T. G. Beckman. 2004. "Armillaria Root and Crown Rot." Southeastern Peach Growers Handbook. http://www.ent.uga.edu/peach/peachhbk/ fungal/armillariacr.pdf.

Davidson, R. M., and R. S. Byther. 1994. Armillaria (Shoestring) Root Rot. Bulletin 1776. Pullman: Washington State University Extension. http://cru.cahe.wsu.edu/CEPublications/eb1776/eb1776.html.

Hagle, S. K. 2008. "Management Guide for Armillaria Root Disease." USDA-Forest Service Forest Health Protection Publication 11.1. http://www.fs.usda.gov/Internet/ FSE_DOCUMENTS/stelprdb5187208.pdf.
Raabe, R. D. 2008. "Plants Resistant or Susceptible to Armillaria mellea, the Oak Root Fungus." University of California. http://mastergardeners.org/pdf/Armillarialist-2008-06-16.pdf.

Sinclair, W. A., and H. H. Lyon. 2005. Diseases of Trees and Shrubs. Ithaca, NY: Cornell Press.

Williams, R. E., C. G. Shaw III, P. M. Wargo, and W. H. Sites. 1986. Armillaria Root Disease. USDA-Forest Service. Forest Insect \& Disease Leaflet 78.

Worrall, J. 2007. “Armillaria Root Disease." http://www. forestpathology.org/dis_arm.html.

Table 1. Resistant species ${ }^{1}$

\begin{tabular}{|c|c|}
\hline Acernegundo* & Box elder \\
\hline Acer rubrum & Southern red maple \\
\hline Acer saccharum & Sugar maple \\
\hline Albizia julibrissin* & Silk tree/mimosa \\
\hline Asimina triloba & Pawpaw \\
\hline Buxus sempervirens & Boxwood \\
\hline Catalpa bignonioides & Southern catalpa \\
\hline Celtis occidentalis & Hackberry \\
\hline Cryptomeria japonica & Japanese cedar \\
\hline Cupressocyparis leylandii & Leyland cypress \\
\hline Diospyros virginiana & Common persimmon \\
\hline Ficus carica 'Kadota' & Kadota fig \\
\hline Ficus carica 'Mission' & Mission fig \\
\hline Ginkgo biloba & Ginkgo \\
\hline Ilex opaca & American holly \\
\hline Ilex cassine & Dahoon \\
\hline Jacaranda acutifolia & Jacaranda \\
\hline Lagerstroemia indica & Crapemyrtle* \\
\hline Liquidambar styraciflua & Sweet gum \\
\hline Liriodendron tulipifera & Tuliptree \\
\hline Magnolia grandiflora & Southern magnolia \\
\hline Maytenus boaria & Mayten tree \\
\hline Morus spp. & Mulberry \\
\hline Myrica pensylvanica & Bayberry \\
\hline Nandina domestica & Heavenly bamboo \\
\hline Platanus species & Sycamore \\
\hline Prunus caroliniana & American cherry laurel \\
\hline Prunus serotina & Black cherry \\
\hline Raphiolepis umbellata & Yedda hawthorn \\
\hline Rhus aromatica & Fragrant sumac \\
\hline Sophora japonica & Japanese pagoda tree \\
\hline Taxodium distichum & Bald cypress \\
\hline
\end{tabular}

